\title{
Mineral Physics Pertinent to the Constitution of the Mantle and Core
}

\author{
Masaki Akaogi \\ Department of Chemistry, Gakushuin University, \\ Toshima-ku, Tokyo 171, Japan
}

\begin{abstract}
Studies on the physical and chemical properties of materials of the earth's and planetary interiors have made remarkable progress in recent years. This paper reviews the important experimental and theoretical results obtained by the Japanese mineral physics community in the last decade. Phase equilibria of mantle minerals were determined in detail at pressure-temperature conditions corresponding to depths down to the lower mantle. Thermodynamic and elastic properties of high pressure silicates were also measured in recent years. These data enable us to calculate seismic velocity and density profiles in the deep mantle, which can be compared with those obtained by seismic studies. Such mineral physics studies demonstrated that pyrolite or peridotite are reasonable model compositions for the upper mantle and the transition zone. However, the lower mantle composition has only been loosely constrained. Melting behaviors of mantle peridotite and related rocks at high pressure were examined in the 1980s. These results suggested the occurrence of fractionation of majorite and perovskite in the magma ocean, when the earth was extensively melted in its accretional stage. Element partitioning experiments, however, concluded that the fractionation of these high pressure phases in the magma ocean is unlikely. Experimental studies on core materials were also made in 1980s. Oxygen and hydrogen were proposed as the light elements in the core on the basis of these experiments. Preliminary results on the reaction and partitioning of the elements between molten iron and silicates were also obtained. However, more extensive experimental studies are needed to constrain the composition of the core and processes at the mantle-core boundary.
\end{abstract}

\section{Introduction}

Mineral physics is a rapidly developing research field, which provides important constraints on models of the constitution and the evolution of the earth and planetary interiors. In 1980s, important progress in mineral physics has been made, especially in studies of the stability and properties of silicate perovskite, melting relations of the mantle and core materials, etc.

One of the most important technical developments in Japanese mineral physics laboratories is in high pressure experiments using large volume multianvil apparatus. Pressures above $25 \mathrm{GPa}$ and temperatures in excess of $2,500^{\circ} \mathrm{C}$ have been generated

Received May 18, 1992; Accepted January 30, 1993. 
with accurate pressure calibration and minimum temperature gradients in the samples. Precise phase equilibrium experiments and the synthesis of large volume of samples, both polycrystalline and single crystals, have been made using these high pressure techniques. In situ x-ray diffraction experiments were also carried out combining the multianvil apparatus with an intense $x$-ray source of synchrotron radiation. This experimental technique has made it possible to directly observe phase transitions and also to accurately determine the equations of state of high pressure phases.

Other important developments have been made in the elastic and calorimetric measurements on the high pressure phases. Minimization of single crystal size to several $10 \mu \mathrm{m}$ in Brillioun scattering experiments has allowed us to measure the elastic constants of high pressure silicate phases. Calorimetric measurements of samples of only about $5 \mathrm{mg}$ provided the transition enthalpies of high pressure silicates, which made it possible for us to accurately calculate the equilibrium phase relations. Although these experimental studies were made mainly in U.S. laboratories, most of the important high pressure samples used in these studies were synthesized in Japanese laboratories with the multianvil apparatus. It should be also noted that theoretical studies on high pressure silicates, which predict the phase transitions and the physical properties that are not accessible in the present state of the art, developed remarkably in the 1980s.

The contents of this paper can be divided into five parts: (1) phase transitions of mantle minerals, (2) physical properties of high pressure silicates, (3) compositional models of the mantle, (4) melting behavior of mantle silicates, and (5) core materials.

\section{Phase Transitions of Mantle Minerals}

Olivine, pyroxene, and garnet are widely accepted as the major constituent minerals of the upper mantle. High pressure transitions of these minerals have been studied extensively since the 1960s. Although most of the phase relations of these minerals were roughly determined by the 1970 s, more detailed studies were made in the 1980 s in order to determine accurate phase diagrams on the basis of high pressure experimental and thermochemical studies.

The olivine $(\alpha)$-modified spinel $(\beta)$-spinel $(\gamma)$ transitions in the system $\mathrm{Mg}_{2} \mathrm{SiO}_{4}(\mathrm{Fo})-$ $\mathrm{Fe}_{2} \mathrm{SiO}_{4}(\mathrm{Fa})$ have been studied since 1960s (see Akimoto, 1987). Recently the phase relations in the $\mathrm{Mg}_{2} \mathrm{SiO}_{4}$-rich portion were extensively reinvestigated by Katsura and Ito (1989) using a multianvil apparatus. They determined the equilibrium boundaries of the $\alpha-\beta-\gamma$ transitions up to $21 \mathrm{GPa}$ and $1,600^{\circ} \mathrm{C}$, performing both normal and reverse experiments (Fig. 1). The chemical compositions of the coexisting phases were also determined in their study. Yagi et al. (1987) determined the $\alpha-\gamma$ transition boundary of $\mathrm{Fe}_{2} \mathrm{SiO}_{4}$ by in situ $x$-ray diffraction method using synchrotron radiation. On the other hand, calorimetric studies were made to obtain the enthalpies of the $\alpha-\beta-\gamma$ transitions in $\mathrm{Mg}_{2} \mathrm{SiO}_{4}$ (Akaogi et al., 1984) and in the system $\mathrm{Mg}_{2} \mathrm{SiO}_{4}-\mathrm{Fe}_{2} \mathrm{SiO}_{4}$ (Akaogi et al., 1989) (Table 1). The calculated phase relations (Fig. 1) were consistent with Katsura and Ito's data and the equilibrium phase boundaries were further extrapolated beyond their experimental ranges. The experimentally determined and calculated widths of the $\alpha-\beta$ transition loop for the upper mantle olivine $(\mathrm{Mg} /(\mathrm{Mg}+\mathrm{Fe})=0.89)$ are consistent 




(a)

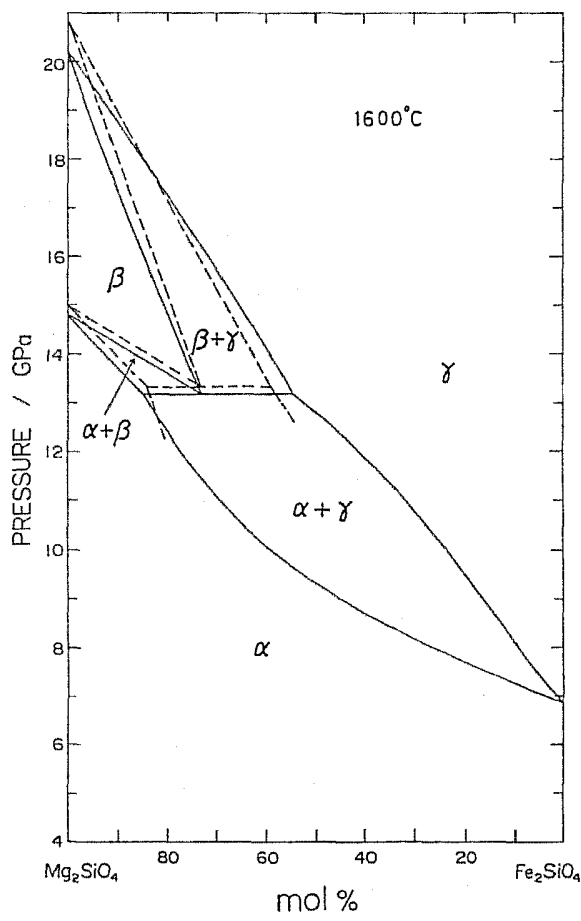

(b)

Fig. 1. Phase relations in the system $\mathrm{Mg}_{2} \mathrm{SiO}_{4}-\mathrm{Fe}_{2} \mathrm{SiO}_{4}$. (a) Phase boundaries experimentally determined at 1,200 and $1,600^{\circ} \mathrm{C}$ (Katsura and Ito, 1989). (b) Calculated phase boundaries (solid curves, Akaogi et al., 1989) and experimentally determined boundaries (dashed curves, Katsura and Ito, 1989) at $1,600^{\circ} \mathrm{C}$. $\alpha$, olivine; $\beta$, modified spinel; $\gamma$, spinel.

with that observed for the $400 \mathrm{~km}$ discontinuity (Katsura and Ito, 1989; Akaogi et al., 1989).

Phase relations in the $\mathrm{Mg}$-rich portion of the system $\mathrm{MgO}-\mathrm{FeO}-\mathrm{SiO}_{2}$ above about $23 \mathrm{GPa}$ are characterized by the formation of $(\mathrm{Mg}, \mathrm{Fe}) \mathrm{SiO}_{3}$ perovskite. Accurate determination of these stability relations is important to clarify the mineralogy of the lower mantle and the nature of the $670 \mathrm{~km}$ discontinuity. Ito and Yamada (1982) examined the phase relations in the system $\mathrm{MgSiO}_{3}-\mathrm{FeSiO}_{3}$ and determined the stability fields of $(\mathrm{Mg}, \mathrm{Fe}) \mathrm{SiO}_{3}$ ilmenite and perovskite. Ito and Takahashi (1989) investigated the corresponding phase relations in the system $\mathrm{Mg}_{2} \mathrm{SiO}_{4}-\mathrm{Fe}_{2} \mathrm{SiO}_{4}$ (Fig. 2). They obtained negative slopes for the ilmenite-perovskite transition in $\mathrm{MgSiO}_{3}$ and for the dissociation of spinel to the assemblage of perovskite + periclase in $\mathrm{Mg}_{2} \mathrm{SiO}_{4}$. They also found that the dissociation of the spinel solid solution into perovskite + magnesiowustite occurs in a very narrow pressure interval $(<0.15 \mathrm{GPa})$ at $1,600^{\circ} \mathrm{C}$. The observed transition pressure and the width of the spinel dissociation reaction supports a model in which the $670 \mathrm{~km}$ discontinuity is attributed to this reaction rather than a chemical 


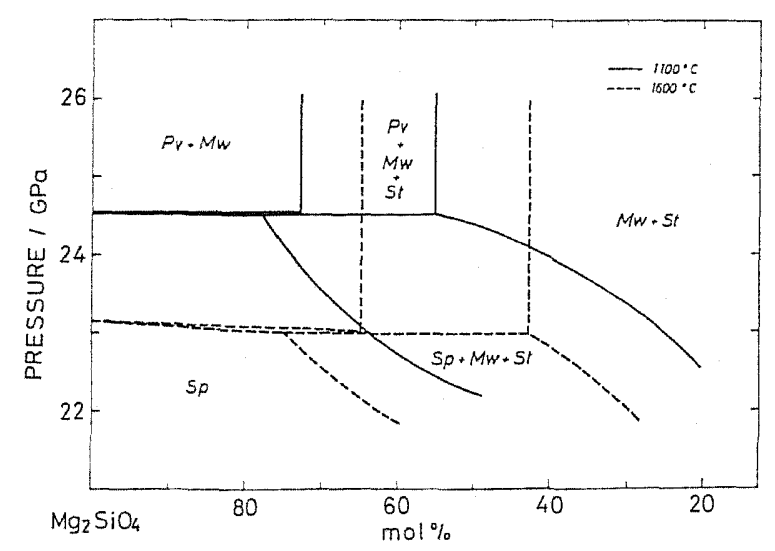

Fig. 2. Phase relations in the system $\mathrm{Mg}_{2} \mathrm{SiO}_{4}-\mathrm{Fe}_{2} \mathrm{SiO}_{4}$. Solid and dashed boundaries are at 1,100 and $1,600^{\circ} \mathrm{C}$, respectively (Ito and Takahashi, 1989). $\mathrm{Sp}$, spinel; Pv, perovskite; Mw, magnesiowustite; St, stishovite.

Table 1. Thermochemical data for transitions of high pressure silicates.

\begin{tabular}{lccc}
\hline Transition & $\begin{array}{c}\Delta H^{*} \\
(\mathrm{~kJ} / \mathrm{mol})\end{array}$ & $\begin{array}{c}\Delta S^{*} \\
(\mathrm{~J} / \mathrm{mol} \cdot \mathrm{K})\end{array}$ & $\begin{array}{c}\Delta V^{i 98} \\
\left(\mathrm{~cm}^{3} / \mathrm{mol}^{*}\right)\end{array}$ \\
\hline & & $\mathrm{Mg}_{2} \mathrm{SiO}_{4}^{\mathrm{a}, \mathrm{b}}$ \\
& $30.0 \pm 2.8$ & $-7.7 \pm 1.9$ & -3.16 \\
$\beta \rightarrow \beta$ & $9.1 \pm 2.1$ & $-7.3 \pm 1.4$ & -0.98 \\
$\gamma \rightarrow \mathrm{Pv}+\mathrm{Per}$ & $96.8 \pm 5.8$ & $11.1 \pm 3.7$ & -3.79 \\
& & $\mathrm{MgSiO}^{\mathrm{b}-\mathrm{e}}$ & -2.74 \\
$\mathrm{Px} \rightarrow \mathrm{Mj}$ & $30.8 \pm 3.1$ & $-4.2 \pm 1.7$ & -2.23 \\
$\mathrm{Mj} \rightarrow \mathrm{Il}$ & $25.0 \pm 5.3$ & $-6.8 \pm 2.3$ & -0.49 \\
$\beta+\mathrm{St} \rightarrow \gamma+\mathrm{St}$ & $4.5 \pm 1.1$ & $-3.5 \pm 0.6$ & -0.42 \\
$\gamma+\mathrm{St} \rightarrow \mathrm{Il}$ & $6.3 \pm 4.8$ & $-2.8 \pm 2.5$ & -1.91 \\
$\mathrm{Il} \rightarrow \mathrm{Pv}$ & $54.7 \pm 6.6$ & $12.8 \pm 2.8$ & \\
& & &
\end{tabular}

${ }^{a}$ Akaogi et al. (1984, 1989), ' ${ }^{\mathrm{b}}$ to et al. (1990), ${ }^{\mathrm{c}}$ Akaogi et al. (1987), ${ }^{\mathrm{d}}$ Ashida et al. (1988), ${ }^{\mathrm{e}}$ Yusa et al. (1993).

change. A calorimetric study of $\mathrm{MgSiO}_{3}$ perovskite (Table 1) by Ito et al. (1990) confirmed the negative slopes for the ilmenite-perovskite transition in $\mathrm{MgSiO}_{3}$ and for the spinel dissociation reaction in $\mathrm{Mg}_{2} \mathrm{SiO}_{4}$. Although the negative slope of the spinel dissociation at the $670 \mathrm{~km}$ discontinuity tends to impede slab subduction, its magnitude may not be large enough to prevent slab penetration at a depth of $670 \mathrm{~km}$.

High pressure transitions of pyroxene and garnet have been also extensively studied. Kato and Kumazawa (1985a) first reported the occurrence of $\mathrm{MgSiO}_{3}$ tetragonal garnet (majorite). Sawamoto (1987) examined the phase relations among pyroxene, garnet, ilmenite, perovskite, and stishovite $+\beta$ (or $\gamma$ ) $-\mathrm{Mg}_{2} \mathrm{SiO}_{4}$ in the $\mathrm{MgSiO}_{3}$ composition. A calorimetric study of the high pressure phases of $\mathrm{MgSiO}_{3}$ made it possible to calculate the equilibrium phase diagrams in $\mathrm{MgSiO}_{3}$ up to $26 \mathrm{GPa}$ and $2,300^{\circ} \mathrm{C}$ using an internally 


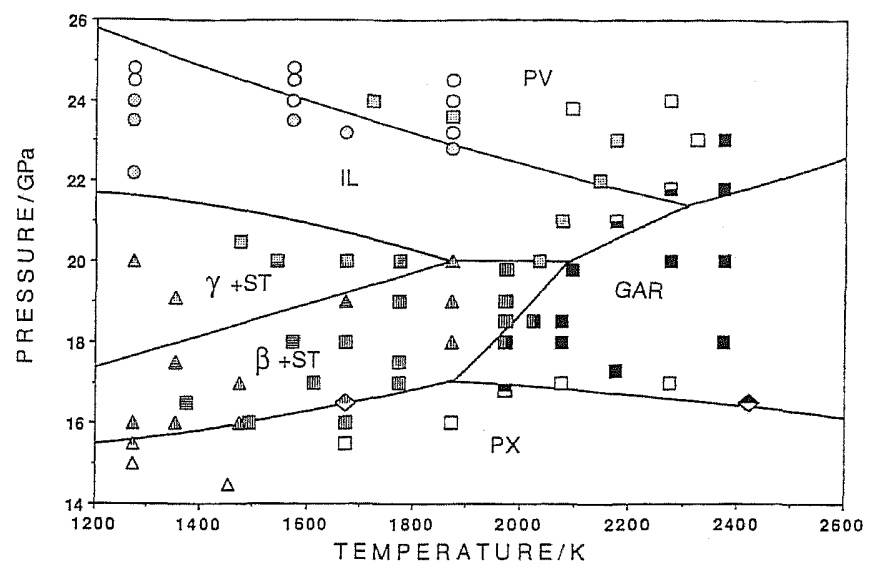

Fig. 3. Phase relations in $\mathrm{MgSiO}_{3}$. Phase boundary curves are thermodynamically calculated (Yusa et al., 1993). Experimental data points are from Ito and Navrotsky (1985) (triangles), Ito and Takahashi (1989) (circles), Sawamoto (1987) (squares), and Presnall and Gasparik (1990) (diamonds). Px, pyroxene; Gar, garnet; Il, ilmenite; Pv, perovskite; $\beta$, modified spinel; $\gamma$, spinel; St, stishovite.

consistent thermodynamic data set (Table 1), as shown in Fig. 3 (Yusa et al., 1993).

The system $\mathrm{Mg}_{4} \mathrm{Si}_{4} \mathrm{O}_{12}(\mathrm{En})-\mathrm{Mg}_{3} \mathrm{Al}_{2} \mathrm{Si}_{3} \mathrm{O}_{12}(\mathrm{Py})$ is an appropriate model for the pyroxene-garnet system in the deep mantle. Kanzaki (1987) determined the stability fields of majorite garnet and ilmenite in this system at pressures up to $22 \mathrm{GPa}$. Irifune and Ringwood (1987a) extended these experiments to $26 \mathrm{GPa}$ and comfirmed the partial solubility of the Py component in $\mathrm{MgSiO}_{3}$ perovskite. Akaogi et al. (1987) calculated the stability field of majorite garnet in the En-Py system, using measured thermochemical data. Their results on the En-Py system are summarized in Fig. 4. The results indicate that, in contrast to the $\alpha-\beta$ and postspinel transitions in the Fo-Fa system, the pyroxene-garnet transition occurs gradually with increasing pressure and is unlikely to yield sharp velocity and density jumps in the mantle.

High pressure transitions of some other important minerals have been also reported. Phase transitions of $\mathrm{CaMgSi}_{2} \mathrm{O}_{6}$ diopside were examined by Irifune et al. (1989) using a multianvil apparatus and by Tamai and Yagi (1989) with a diamond anvil cell. Their results showed that at pressures above about $17 \mathrm{GPa}$ diopside dissociates into $\mathrm{CaSiO}_{3}$ perovskite and $\mathrm{MgSiO}_{3}$ components, the latter being $\beta$ - or $\gamma-\mathrm{Mg}_{2} \mathrm{SiO}_{4}+$ stishovite, ilmenite, and perovskite, depending on pressure. Yagi et al. (1989) confirmed that $\mathrm{CaSiO}_{3}$ perovskite is stable in the whole range of lower mantle conditions. An $\mathrm{MgAl}_{2} \mathrm{O}_{4}$ phase with a calcium ferrite structure was synthesized by Irifune et al. (1991). Tsuchida and Yagi (1989) found that stishovite transforms to a $\mathrm{CaCl}_{2}$ structure at about $90 \mathrm{GPa}$, which might be stable in the $\mathrm{D}^{\prime \prime}$ layer of the lowermost mantle.

In addition to the phase transition experiments on the simple systems described above, the corresponding model mantle compositions have been examined experimentally. Akaogi and Akimoto (1979) examined phase equilibria of a peridotitic com- 


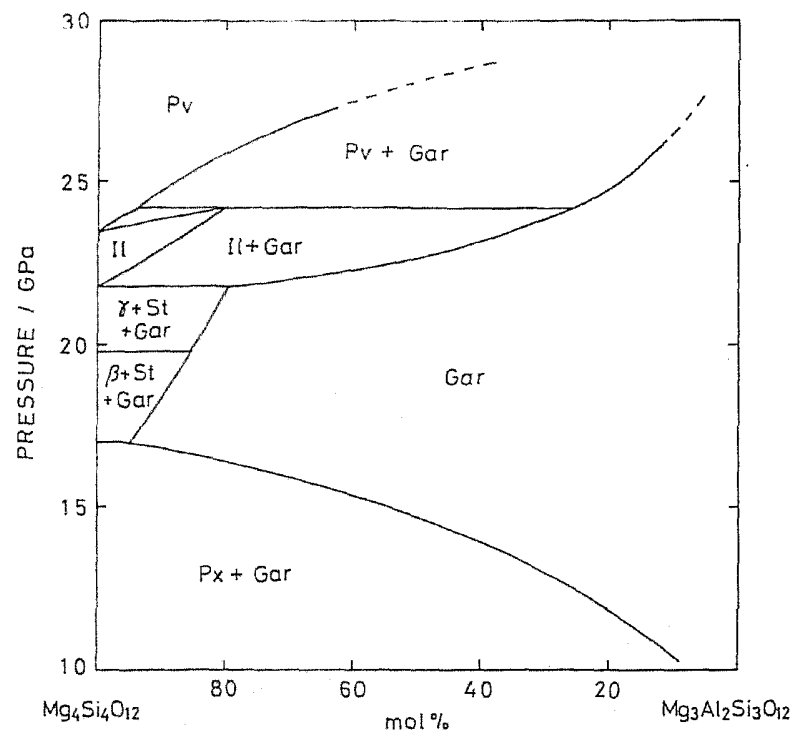

Fig. 4. Phase relations in the system $\mathrm{Mg}_{4} \mathrm{Si}_{4} \mathrm{O}_{12}-\mathrm{Mg}_{3} \mathrm{Al}_{2} \mathrm{Si}_{3} \mathrm{O}_{12}$ at $1,500^{\circ} \mathrm{C}$ (Irifune and Ringwood, 1987a; Akaogi et al., 1987b). Px, pyroxene; Gar, garnet; Il, ilmenite; Pv, perovskite; $\beta$, modified spinel; $\gamma$, spinel; St, stishovite.

position close to pyrolite up to about $20 \mathrm{GPa}$. Takahashi and Ito (1987) extended these experiments to pressures over $25 \mathrm{GPa}$ and $1,600^{\circ} \mathrm{C}$. These studies confirmed that the major phase transitions observed in the simple systems occurred in a similar manner in the model mantle compositions, and also determined the partitioning of major elements among the coexisting phases. Phase equilibrium experiments up to about $27 \mathrm{GPa}$ and $1,600^{\circ} \mathrm{C}$ were made by Ito and Takahashi (1987a) in the system $\mathrm{CaSiO}_{3}-$ $\mathrm{MgSiO}_{3}-\mathrm{Al}_{2} \mathrm{O}_{3}$ and by Irifune and Ringwood (1987b) in a pyrolitic composition. Their studies clarified the formation of majorite up to about $16 \mathrm{GPa}$ and the dissociation of majorite garnet to $\mathrm{MgSiO}_{3}$-rich perovskite (or ilmenite) plus $\mathrm{CaSiO}_{3}$ perovskite (and Al-rich unknown phase) above about 20-23 GPa. Figure 5 summarizes the change of mineral proportions in a pyrolite mantle at depths down to the lower mantle. Although the transitions in the Fo-Fa system have been examined in detail, the post-majorite transitions above about $20 \mathrm{GPa}$ have been only poorly understood. Several possible post-majorite aluminous phases have been reported: perovskite s.s. in the En-Py system, $\mathrm{MgAl}_{2} \mathrm{O}_{4}$ calcium ferrite, $\varepsilon-\mathrm{MgAl}_{2} \mathrm{O}_{4}$ (Liu, 1978), and $\mathrm{Ca}, \mathrm{Mg}$-hollandite (Madon et al., 1989). Phase transitions in eclogite and harzburgite compositions were also studied by Irifune and Ringwood (1987a, b), who discussed the effects of these phase transitions on the slab subduction in the deep mantle.

It is well known that small amounts of volatile components such as $\mathrm{H}_{2} \mathrm{O}$ and $\mathrm{CO}_{2}$ cause considerable effects on the melting behavior and the physical properties of silicates. However, hydrous silicates and carbonates stable in the transition zone and the lower mantle have remained unclarified. A hydrous silicate phase B in the system $\mathrm{MgO}-$ $\mathrm{SiO}_{2}-\mathrm{H}_{2} \mathrm{O}$ was confirmed to have a high density and be stable at pressures $10-20 \mathrm{GPa}$ 


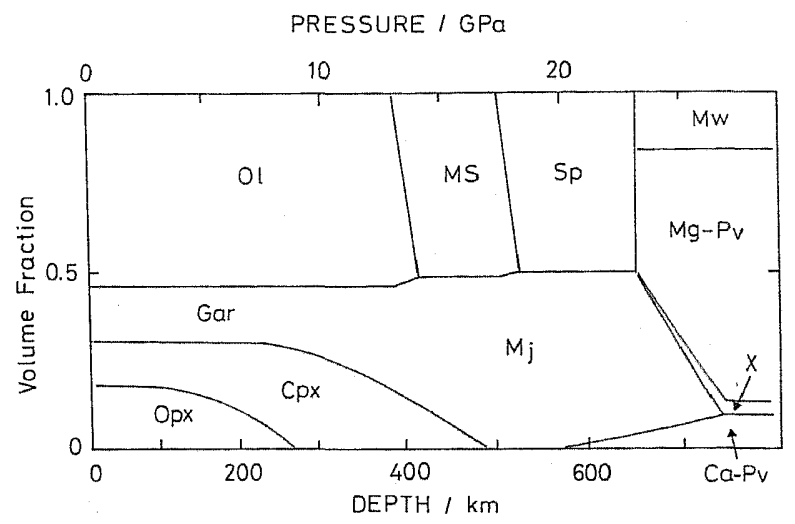

Fig. 5. Volumetric mineral constitution of pyrolite down to the uppermost lower mantle (Ito and Takahashi, 1987a; Irifune and Ringwood, 1987b). Ol, olivine; MS, modified spinel; Sp, spinel; Opx, Ca-poor pyroxene; Cpx, Ca-rich pyroxene; $\mathrm{Gar}$, garnet; $\mathrm{Mj}$, majorite garnet solid solution; $\mathrm{Mg}-\mathrm{Pv}, \mathrm{MgSiO}_{3}$-rich perovskite; $\mathrm{Ca}-\mathrm{Pv}, \mathrm{CaSiO}_{3}$-rich perovskite; $\mathrm{Mw}$, magnesiowustite; $\mathrm{X}, \mathrm{Al}$-rich unknown phase.

(Akaogi and Akimoto, 1980, 1986; Kato and Kumazawa, 1985b). The crystal structure and the exact composition of phase B were determined later by Finger et al. (1989), who also found anhydrous phase B possessed the structure and composition relevant to the hydrous phase B. Kanzaki (1991) examined the phase relations in the $\mathrm{MgO}-$ $\mathrm{SiO}_{2}-\mathrm{H}_{2} \mathrm{O}$ system and found two new phases, denoted $\mathrm{E}$ and $\mathrm{F}$, which are stable at about $13-17 \mathrm{GPa}$. These phases, especially hydrous phase $\mathrm{B}$, may be important hydrous silicates present in the transition zone in relatively low temperature regions, such as the subduction zone.

\section{Physical Properties of High-Pressure Silicates}

Elasticity data on mantle minerals are indispensable to evaluate mineralogical mantle models in the light of the observed seismic velocity profiles. The elastic properties of important high pressure silicates were determined under ambient conditions mostly by Brillioun scattering techniques. These include $\beta-\mathrm{Mg}_{2} \mathrm{SiO}_{4}$ (Sawamoto et al., 1984), $\gamma-\mathrm{Mg}_{2} \mathrm{SiO}_{4}$ (Weidner et al., 1984), $\mathrm{MgSiO}_{3}$ ilmenite (Weidner and Ito, 1985), and $\mathrm{MgSiO}_{3}$ perovskite (Yeganeh-Haeri et al., 1989), which were synthesized as single crystals of several $10 \mu \mathrm{m}$ in diameter using a multianvil apparatus (Ito and Weidner, 1986; Sawamoto, 1986). Bulk moduli of polycrystalline $\mathrm{MgSiO}_{3}$ majorite and $\mathrm{Mg}_{4} \mathrm{Si}_{4} \mathrm{O}_{12}-\mathrm{Mg}_{3} \mathrm{Al}_{2} \mathrm{Si}_{3} \mathrm{O}_{12}$ garnets were measured in compression experiments using synchrotron radiation x-ray diffraction (Yagi et al., 1987, 1992). These elastic data are listed in Table 2.

The rectangular parallelepiped resonance (RPR) method has also been used to measure the elastic properties of mantle minerals. Although this technique has been applied only to minerals stable at 1 bar because relatively large crystals ( $\gtrsim 1 \mathrm{~mm}$ in 
Table 2. Physical properties of high pressure silicates.

\begin{tabular}{|c|c|c|c|c|c|c|c|}
\hline Phase & $\begin{array}{c}K_{0 \mathrm{~s}} \\
(\mathrm{GPa})\end{array}$ & $K_{\text {os }}^{\prime}$ & $\begin{array}{c}\mu_{0} \\
(\mathrm{GPa})\end{array}$ & $\mu_{0}^{\prime}$ & $\begin{array}{c}\alpha_{0} \\
\left(\times 10^{-6} \mathrm{~K}^{-1}\right)\end{array}$ & $\gamma_{0}$ & $\delta_{\mathrm{s}}$ \\
\hline$\alpha-\mathrm{Mg}_{2} \mathrm{SiO}_{4}$ & 129 & 5.1 & 82 & 1.8 & 26.2 & 1.25 & 4 \\
\hline$\beta-\mathrm{Mg}_{2} \mathrm{SiO}_{4}$ & $174^{\mathrm{a}}$ & $4.8^{\mathrm{g}}$ & $114^{\mathrm{a}}$ & $1.7^{\mathrm{g}}$ & $20.6^{\mathrm{j}}$ & 1.3 & 3 \\
\hline$\gamma-\mathrm{Mg}_{2} \mathrm{SiO}_{4}$ & $184^{\mathrm{b}}$ & $5.0^{\mathrm{h}}$ & $119^{b}$ & $1.7^{\mathrm{h}}$ & $18.6^{\mathrm{k}}$ & 1.35 & 3 \\
\hline $\mathrm{MgSiO}_{3} \mathrm{Px}$ & 108 & $5.0^{\mathrm{i}}$ & 77 & $2.0^{\mathrm{i}}$ & 27 & 1.1 & 6 \\
\hline $\mathrm{MgSiO}_{3} \mathrm{Mj}$ & $161^{\mathrm{c}}$ & $4.9^{i}$ & $90^{\mathrm{i}}$ & $1.4^{\mathrm{i}}$ & 18 & 1.1 & 6 \\
\hline $\mathrm{MgSiO}_{3} \mathrm{Il}$ & $212^{d}$ & $4.3^{\mathrm{i}}$ & $132^{d}$ & $1.7^{\mathrm{i}}$ & $24^{1}$ & $1.5^{1}$ & $5^{p}$ \\
\hline $\mathrm{MgSiO}_{3} \mathrm{PV}$ & $246^{\mathrm{e}}$ & $3.9^{\mathrm{i}}$ & $184^{\circ}$ & $2.0^{\mathrm{i}}$ & $20^{m}$ & $1.5^{\circ}$ & $5^{p}$ \\
\hline $\mathrm{CaSiO}_{3} \mathrm{Pv}$ & $288^{f}$ & $3.9^{\mathrm{i}}$ & $125^{\mathrm{i}}$ & $1.9^{\mathrm{i}}$ & $20^{\mathrm{n}}$ & $1.5^{\mathrm{n}}$ & $5^{p}$ \\
\hline
\end{tabular}

${ }^{a}$ Sawamoto et al. (1984); ' Weidner et al. (1984); 'Yagi et al. (1992); 'Weidner and Ito (1985); e Yeganeh-Haeri et al. (1989); ${ }^{\mathrm{f}}$ Yagi et al. (1989); ${ }^{\mathrm{g}}$ Gwanmesia et al. (1990); ${ }^{\mathrm{h}}$ Rigden et al. (1991); ${ }^{\mathrm{i}}$ estimated by Duffy and Anderson (1989); ${ }^{j}$ Suzuki et al. (1980); ${ }^{\mathrm{k}}$ Suzuki et al. (1979); ${ }^{1}$ Ashida et al. (1988); ${ }^{\mathrm{m}}$ Ross and Hazen (1989); ${ }^{\mathrm{n}}$ same as $\mathrm{MgSiO}_{3}$ perovskite; ${ }^{\circ}$ Akaogi and Ito (1993); ${ }^{\mathrm{p}}$ assumed; others: compiled by Jeanloz and Thompson (1983) and Irifune (1987).

edge length) are needed for the measurements, accurate measurements at room and high temperatures are possible in this method. The high temperature elastic properties of $\mathrm{Mg}_{2} \mathrm{SiO}_{4}$ and $\mathrm{Fe}_{2} \mathrm{SiO}_{4}$ olivines, $\mathrm{MgO}$ and pyrope garnet were measured by this method (Sumino, 1979; Sumino et al., 1983; Suzuki and Anderson, 1983). Techniques for ultrasonic measurements at high pressure have also been developed, and the pressure derivatives of elastic constants of minerals including $\mathrm{MgO}$ and $\mathrm{MgAl}_{2} \mathrm{O}_{4}$ spinel were reported (Yoneda, 1990; Fujisawa and Ito, 1984).

Thermal expansion data are also important to constrain the mineralogy of the mantle. The thermal expansion of some high pressure silicates were measured at 1 bar: $\beta$ - and $\gamma-\mathrm{Mg}_{2} \mathrm{SiO}_{4}$ (Suzuki et al., 1979, 1980), $\mathrm{Fe}_{2} \mathrm{SiO}_{4}$ olivine and spinel (Suzuki et al., 1981; Yamanaka, 1986), and $\mathrm{MgSiO}_{3}$ ilmenite (Ashida et al., 1988). The results are shown in Table 2. Although much effort has been directed to the experimental determination of the thermal expansion of $\mathrm{Mg}$-rich perovskite because of its prime importance in the estimation of lower mantle mineralogy, the reliability of the obtained data is still controversial (see Wang et al., 1991, and the references therein). Since the uncertainty of the thermal expansion of $\mathrm{Mg}$-rich perovskite is probably caused by marginal metastability of perovskite at high temperature and 1 bar, thermal expansion measurements in its stability field are highly desirable.

The heat capacities of high pressure minerals are also important thermophysical data which are necessary to evaluate the Debye temperature and Gruneisen parameter. Watanabe $(1982)$ and Ashida et al. $(1987,1988)$ measured the heat capacities of $\alpha-\beta$ $\gamma-\mathrm{Mg}_{2} \mathrm{SiO}_{4}$, and $\mathrm{MgSiO}_{3}$ ilmenite, while Akaogi and Ito (1993) have reported the heat capacity of $\mathrm{MgSiO}_{3}$ perovskite.

Theoretical studies of the crystal structure and the physical properties of high pressure silicates have also been made on the basis of molecular dynamics and first principle calculations (Matsui and Kawamura, 1987; Matsui et al., 1987; Matsui, 1988; Park et al., 1988). The results of these theoretical studies are generally in good agreement 
with the experimentally determined physical properties and structures. This agreement gives credibility to the theoretically predicted structures and physical properties of high pressure silicates at very high pressure and high temperature which are still inaccessible to experimental studies.

We now discuss some theoretical results closely related to the constitution of the mantle. The transition of stishovite into a dense phase with the $\mathrm{Pa} \overline{3}$ symmetry was predicted by theoretical calculations (Matsui and Matsui, 1988; Park et al., 1988). Although Tsuchida and Yagi (1989) found experimentally that stishovite first undergoes a transition to the $\mathrm{CaCl}_{2}$ structure at about $90 \mathrm{GPa}$, the decomposition of $(\mathrm{Mg}, \mathrm{Fe}) \mathrm{SiO}_{3}$ perovskite into $(\mathrm{Mg}, \mathrm{Fe}) \mathrm{O}$ plus $\mathrm{Pa} \overline{3}$-type $\mathrm{SiO}_{2}$ might occur at higher pressures. A theoretical study by Wolf and Bukowinski (1987) showed ferroelastic behavior of silicate perovskite, which would cause successive transitions from orthorhombic to cubic via tetragonal symmetry under lower mantle conditions. Drastic changes in the physical properties might be present in association with these transitions. Matsui and Price (1991) showed a similar transition of $\mathrm{MgSiO}_{3}$ perovskite from orthorhombic to cubic structure. The latter phase was predicted to have a high ionic conductivity at very high temperatures near the melting point at high pressure.

\section{Compositional Models of the Mantle}

Compositional and mineralogical models of the upper and lower mantle are the subject of vigorous debate. Possible compositional difference between the upper mantle (above $670 \mathrm{~km}$ in depth) and the lower mantle (below $670 \mathrm{~km}$ ) has been discussed extensively from the viewpoints of geophysics, mineral physics, and geochemistry (e.g., Silver et al., 1988). In a chemically homogeneous mantle model, the upper mantle and the lower mantle are assumed to have the same pyrolitic composition, and whole mantle convection is expected to occur. However, in a chemically stratified mantle model, the lower mantle is intrinsicly denser ( $\mathrm{SiO}_{2}$-rich or $\mathrm{FeO}$-rich) than the upper mantle because of the compositional difference, and two-layer convection is likely to occur. A different stratified mantle model has also been proposed, where the transition zone has a picritic eclogite (piclogite) composition, with the peridotitic upper mantle above $400 \mathrm{~km}$ depth and the perovskite lower mantle (Anderson and Bass, 1986).

The phase relations and the physical properties of the high pressure minerals described in the previous sections provide constraints on mantle models from two directions. First, the phase relations established by high pressure experiments and thermodynamic calculations define the depths and the sharpness of the phase transitions which should occur in the mantle. Second, the measurements of the elastic moduli and their pressure and temperature dependences enable us to calculate the velocity and density profiles for given model mantle compositions, which are then compared with those obtained from seismic observations.

Seismological studies indicate that the $670 \mathrm{~km}$ discontinuity is very sharp (e.g., Nakanishi, 1988). Some earlier studies concluded that the $670 \mathrm{~km}$ discontinuity could not be attributed to the dissociation of $(\mathrm{Mg}, \mathrm{Fe})_{2} \mathrm{SiO}_{4}$ spinel into $(\mathrm{Mg}, \mathrm{Fe}) \mathrm{SiO}_{3}$ perovskite and $(\mathrm{Mg}, \mathrm{Fe}) \mathrm{O}$, because this reaction was expected to be spread out over a depth range of more than 20-30 km (Jeanloz and Thompson, 1983; Lees et al., 1983). However,

Vol. 43, No. 4, 1995 
refinements of the phase relations demonstrated that this reaction occurs in a very narrow pressure interval corresponding to a depth range of at most $4 \mathrm{~km}$ (Ito and Takahashi, 1989), which is consistent with seismic observations of the $670 \mathrm{~km}$ discontinuity. Anderson and Bass (1986) argued that the observed velocity increase is rather abrupt at the $400 \mathrm{~km}$ discontinuity and therefore it could not correspond to the $\alpha-\beta$ transition in the system $\mathrm{Mg}_{2} \mathrm{SiO}_{4}-\mathrm{Fe}_{2} \mathrm{SiO}_{4}$. The phase relations established by subseqeunt high pressure experiments and themodymanic studies, however, demonstrated that the $\alpha-\beta$ transition occurs in a depth interval of $10-20 \mathrm{~km}$ (Katsura and Ito, 1989; Akaogi et al., 1989), which is in good agreement with the seismic observations.

The elastic constants of important high pressure silicates were measured under the ambient conditions, as discussed in the previous section. Using these elastic data, the velocity and density profiles were calculated and compared with the seismological models (Weidner and Ito, 1987; Akaogi et al., 1987; Irifune, 1987; Duffy and Anderson, 1989). One of the results obtained by Weidner and Ito (1987) is shown in Fig. 6. The observed velocity jumps at the $400 \mathrm{~km}$ discontinuity are about $40 \%$ of the velocity changes for the $\alpha-\beta$ transition of mantle olivine under ambient conditions. However, this does not necessarily mean that the mantle is composed of only $40 \%$ olivine at the $400 \mathrm{~km}$ depth, because the velocity jump for the $\alpha-\beta$ transition is very sensitive to the pressure and temperature derivatives of the elastic constants of $\beta$-phase (Weidner and Ito, 1987). In fact, Gwanmesia et al. (1990) and Rigden et al. (1991) concluded that models with olivine content in a range from 45 to $65 \%$ are acceptable on the basis of their measurements of pressure derivatives of the elastic moduli of $\beta-\mathrm{Mg}_{2} \mathrm{SiO}_{4}$.

The transition zone between 400 and $670 \mathrm{~km}$ is marked by high gradients of the seismic velocities (e.g., Dziewonski and Anderson, 1981). The steep gradients may be explained by the successive phase transitions in the pyrolite mantle: the $\beta$ - $\gamma$ transition in olivine, the pyroxene-garnet transition, and the post-majorite transition including the exsolution of $\mathrm{CaSiO}_{3}$ perovskite. In the piclogitic model (Anderson and Bass, 1986),

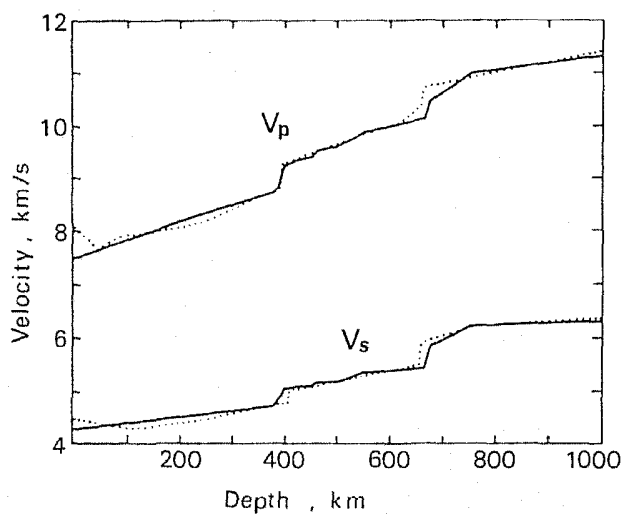

Fig. 6. Comparison of observed and calculated P- and S-wave velocities in the mantle (Weidner and Ito, 1987). Dotted curves are from the seismic studies by Walck (1984) and Grand and Helmberger (1984). Solid curves are the calculated velocities from the elasticity data. 
the steep velocity gradients were explained by the pyroxene-garnet transition, where a very high bulk modulus for majorite garnet was assumed on the basis of earlier experiments by Jeanloz (1981). However, Akaogi et al. (1987) showed that the piclogitic transition zone gives smaller velocity gradients, using the new bulk modulus data for majorite of Yagi et al. (1987), and is accordingly inconsistent with seismic observations.

The boundary region between the transition zone and the lower mantle is marked by the presence of a very sharp velocity jump at $670 \mathrm{~km}$ and also a high velocity gradient at depths of about $600-800 \mathrm{~km}$ (Fig. 6). These features are explained in the pyrolitic mantle model as follows. The former jump is due to the spinel dissociation into perovskite and magnesiowustite, while the latter represents the smeared out transition of majorite garnet to denser phases including $\mathrm{CaSiO}_{3}$ - and $\mathrm{MgSiO}_{3}$-rich perovskites at depths of about $650-750 \mathrm{~km}$ (Ito and Takahashi, 1987a). The velocities in the lower mantle are consistent with those of the mixture of perovskite and magnesiowustite in the pyrolitic composition, as shown in Fig. 6. However, alternative compositional models with a $\mathrm{SiO}_{2}$-rich or FeO-rich lower mantle are still acceptable, when we consider uncertainties in the pressure and temperature derivatives of the elastic moduli of the relevant high pressure phases (Weidner and Ito, 1987; Duffy and Anderson, 1989). It has been pointed out that the thermal expansion of $(\mathrm{Mg}, \mathrm{Fe}) \mathrm{SiO}_{3}$ perovskite provides a very important constraint to test the compositional models of the lower mantle (Jackson, 1983; Jeanloz and Thompson, 1983). Recent analyses of thermal expansion show that the pyrolitic composition fits the seismic data better than the other compositional models (Chopelas and Boehler, 1989).

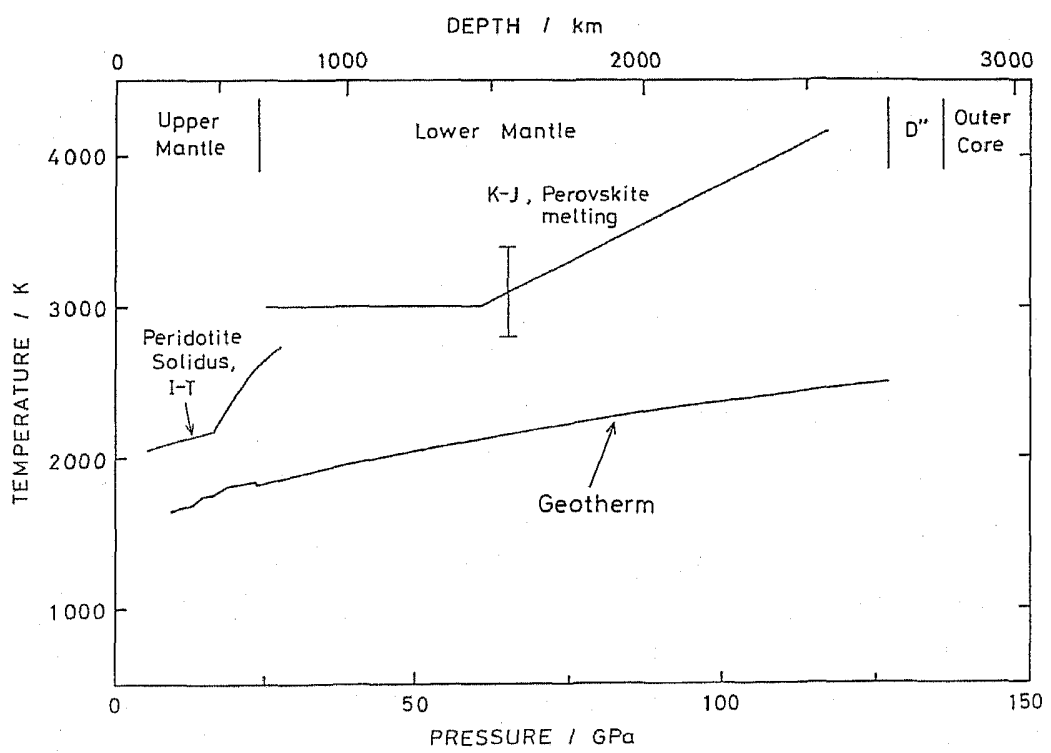

Fig. 7. Temperature distribution in the pyrolite mantle (Ito and Katsura, 1989; Akaogi et al., 1989; Akaogi and Ito, 1993). Solidus of dry peridotite (I-T, Ito and Takahashi, 1987b) and melting curve of $\left(\mathrm{Mg}_{0.9}, \mathrm{Fe}_{0.1}\right) \mathrm{SiO}_{3}$ perovskite (K-J, Knittle and Jeanloz, 1989a) are also shown. 
Temperatures in the transition zone have been often estimated using the phase diagrams of the $\mathrm{Mg}_{2} \mathrm{SiO}_{4}-\mathrm{Fe}_{2} \mathrm{SiO}_{4}$ system. Recently Ito and $\mathrm{Katsura}$ (1989) and Akaogi et al. (1989) estimated the temperatures at the 400 and $670 \mathrm{~km}$ discontinuities as 1,400 and $1,600^{\circ} \mathrm{C}$, respectively, from the locations of the $\alpha-\beta$ and postspinel transitions. Akaogi and Ito (1993) further calculated the adiabatic temperature profile in the lower mantle. Figure 7 illustrates the temperature profiles thus obtained for the upper and lower mantle. In a chemically stratified mantle model with layered convection, the temperature in the lower mantle is expected to be higher than that in a homogeneous mantle model with whole mantle convection. However, even in the former case, the temperature should be lower than the melting temperature of $\mathrm{MgSiO}_{3}$-rich perovskite. Figure 7 also shows the melting curve of perovskite by Knittle and Jeanloz (1989a) using diamond anvils, and that determined for peridotite by Ito and Takahashi (1987b) with a multianvil apparatus. The present geotherm is indeed far below these melting curves throughout the mantle.

\section{Melting Behaviors of Mantle Silicates}

Melting of silicates is an essential process of magma generation, and is thought to be one of the most important processes controlling the evolution of the earth's mantle. Until the 1970 s the melting relations of silicate minerals were studied from a petrological point of view, mostly at pressures below $4 \mathrm{GPa}$. Development of multianvil techniques made it possible to investigate melting relations at pressure above $20 \mathrm{GPa}$ and temperatures higher than $2,000^{\circ} \mathrm{C}$. Using these techniques melting experiments were carried out in several simple silicate systems including $\mathrm{Mg}_{2} \mathrm{SiO}_{4}$ and $\mathrm{Fe}_{2} \mathrm{SiO}_{4}$ (Ohtani, 1979; Ohtani and Kumazawa, 1981).

Melting relations of mantle peridotites and related rocks were studied at pressures of 10-25 GPa using multianvil apparatus in the last decade. These studies were carried out on the assumption that global melting had occurred during the early stage of the earth's history (e.g., Abe and Matsui, 1985; Sasaki and Nakazawa, 1986). Takahashi and Scarfe (1985) and Takahashi (1986) investigated the melting relations of mantle peridotite at pressures up to $15 \mathrm{GPa}$, and found that the melting temperature interval between the solidus and liquidus of peridotite decreases significantly with increasing pressure, accompanied by a change of the liquid composition from basaltic to komatiitic. Ito and Takahashi (1987b) and Ohtani and Sawamoto (1987) extended the melting experiments of the peridotitic and chondritic compositions to $25 \mathrm{GPa}$ (Fig. 8). They found that the liquidus phase is olivine at pressures below about $15 \mathrm{GPa}$, majorite garnet at $15-25 \mathrm{GPa}$, and $\mathrm{Mg}$-perovskite above $25 \mathrm{GPa}$. These experimental results would have important implications for the evolution of the mantle, if the global melting more than several hundred $\mathrm{km}$ in depth (magma ocean) occurred in the accretional stage of the earth. The above experimental results suggest that fractionation of olivine, majorite, and $\mathrm{MgSiO}_{3}$-rich perovskite could occur at the corresponding depths in the deep mantle and that the primitive mantle should be chemically stratified.

Experiments on element partitioning between the high pressure silicates and the coexisting melts impose very important constraints on the above models of fractionation of high pressure phases in the deep mantle. Ohtani et al. (1989) and Yurimoto and 


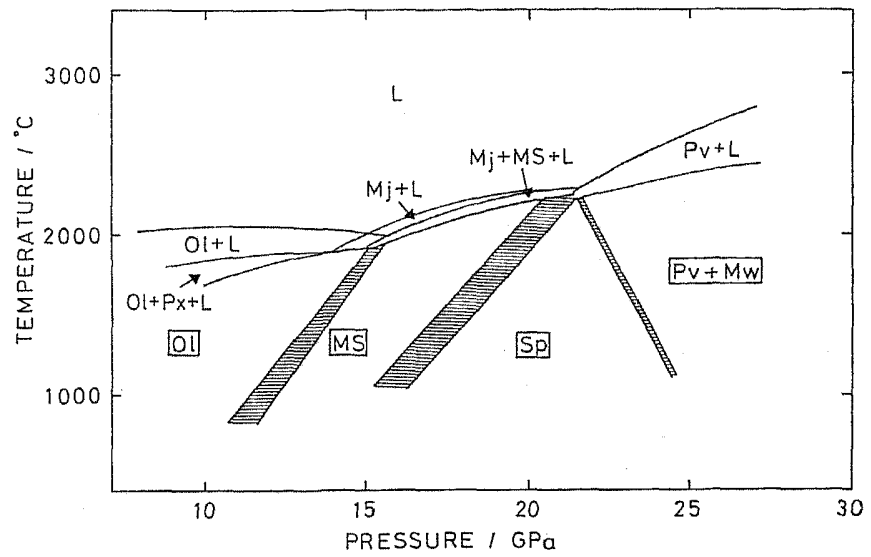

Fig. 8. Melting relations of peridotite (Ohtani and Sawamoto, 1987; Ito and Takahashi, 1987 b). Dominant subsolidus phases are shown with symbols in boxes: Ol, olivine; MS, modified spinel; Sp, spinel; Pv, perovskite; Mw, magnesiowustite. Other phases are: $\mathrm{Px}, \mathrm{Ca}$-poor pyroxene; $\mathrm{Mj}$, majorite; $\mathrm{L}$, liquid. Shaded areas are transition intervals in the system $\mathrm{Mg}_{2} \mathrm{SiO}_{4}-\mathrm{Fe}_{2} \mathrm{SiO}_{4}$.

Ohtani (1992) investigated partitioning of minor and trace elements between majorite garnet and silicate melt at $16-20 \mathrm{GPa}$, and discussed possible fractionation of majorite together with the genesis of various types of komatiites. Ito and Takahashi (1987b) examined the partitioning of major elements at $25 \mathrm{GPa}$ and concluded that $\mathrm{MgSiO}_{3}$ - and $\mathrm{CaSiO}_{3}$-rich perovskites could be fractionated, if any, only in a small extent. Kato et al. $(1988 \mathrm{a}, \mathrm{b})$ determined the partition coefficients of major and trace elements among the Mg- and Ca-perovskites, majorite, and melts. They concluded that there is no evidence of gross differentiation in a mantle controlled by majorite or $\mathrm{Mg}$-perovskite fractionation. These results, however, do not rule out the possibility of fractionation in the primitive mantle, because the subsequent vigorous convection in the mantle could have obliterated the evidence of the stratification formed in the earlier stage.

The density and viscosity of silicate melts are very important properties in understanding magmatic processes. It has been suggested that, in some depth ranges of the mantle basaltic melts could be denser than the surrounding peridotitic mantle (Stolper et al., 1981). This density-crossover at high pressure may have significant implications for the evolution of the mantle. However, only a few experiments have been carried out for measurements of the density and the viscosity of silicate melts at high pressures, because of experimental difficulties. At pressures up to $2 \mathrm{GPa}$, Taniguchi (1989) measured densities of the silicate melts in the system $\mathrm{CaMgSi}_{2} \mathrm{O}_{6}-\mathrm{CaAl}_{2} \mathrm{Si}_{2} \mathrm{O}_{8}$ by the sinking/floating sphere method. A new technique to measure viscosity and density of silicate melts at high pressures was developed by Kanzaki et al. (1987), who directly observed sinking $\mathrm{Pt}$ (or $\mathrm{Mo}$ ) spheres in $\mathrm{NaAlSi}_{3} \mathrm{O}_{8}$ and $\mathrm{Na}_{2} \mathrm{Si}_{2} \mathrm{O}_{5}$ melts at $3 \mathrm{GPa}$ with an $\mathrm{X}$-ray shadowgraph using synchrotron radiation. 


\section{Core Materials}

The earth's core consists of a liquid outer core and a solid inner core, which are made mostly of iron alloyed with small amounts of nickel. The phase relations of pure iron at high pressures and high temperatures are therefore of basic importance to understand the state of the core. The $\alpha-\gamma-\varepsilon$ transition boundaries of iron were recently reexamined by an x-ray diffraction study using synchrotron radiation (Akimoto et al., 1987). It was found that the density of the outer core is about $10 \%$ lower than that of pure iron at the relevant $\mathrm{P}, \mathrm{T}$ conditions. This implies that some light elements should also exist in the outer core. Until the 1970s silicon and sulfur were considered as the leading candidates for the light elements. Ringwood (1979) discussed the possibility that the oxygen solubility in molten iron increases with pressure, and proposed that oxygen is probably the principal light element in the outer core. Ohtani et al. (1984) and Kato and Ringwood (1989) experimentally confirmed the increase of oxygen solubility in molten iron with pressure, suggesting complete miscibility between $\mathrm{Fe}$ and $\mathrm{FeO}$ liquids at $25 \mathrm{GPa}$ and $2,200^{\circ} \mathrm{C}$. In experiments on the systems $\mathrm{Fe}-\mathrm{FeO}-\mathrm{FeS}$ and $\mathrm{Fe}-\mathrm{Ni}-\mathrm{O}-\mathrm{S}$, Urakawa et al. (1987) found that the eutectic temperatures decrease by several hundred degrees as compared with the melting temperature of pure iron at $15 \mathrm{GPa}$. They also found a much smaller pressure dependence for these eutectic temperatures. These results suggest that the melting point of iron decreases by more than one thousand degrees in the presence of oxygen and sulfur under the core's P,T conditions (Fig. 9).

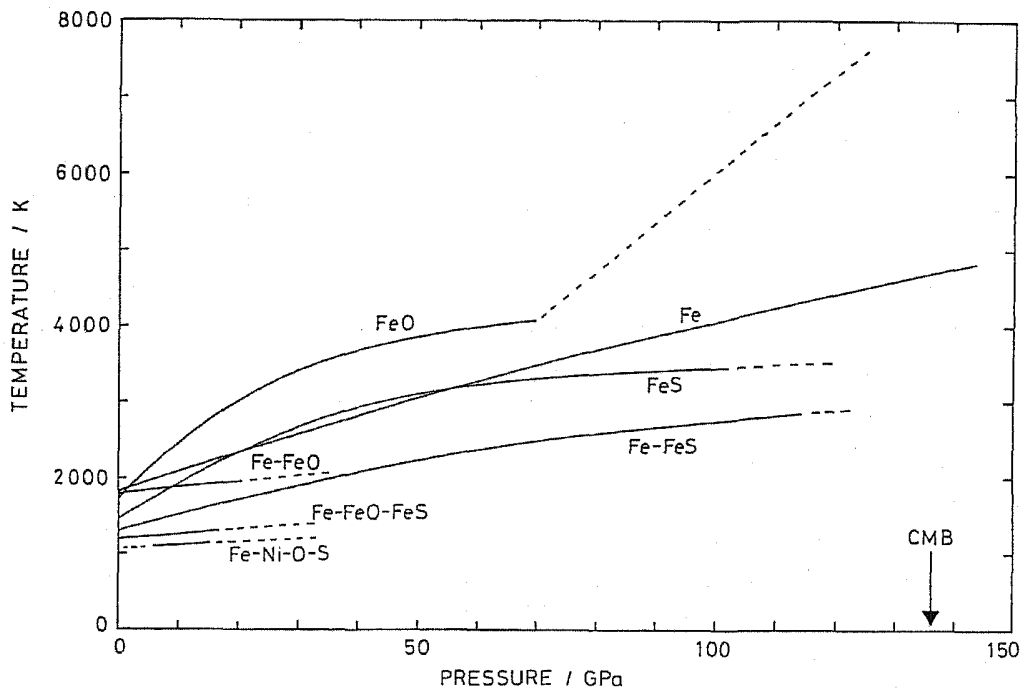

Fig. 9. Melting curves of core materials at high pressures. Melting temperatures of $\mathrm{Fe}$ (Williams et al., 1987), $\mathrm{FeO}$ (Knittle and Jeanloz, 1991), and FeS (Williams and Jeanloz, 1990) are shown. Eutectic temperatures are also shown in $\mathrm{Fe}-\mathrm{FeO}$ system (Ohtani et al., 1984; Kato and Ringwood, 1989), Fe-FeS system (Williams and Jeanloz, 1990), and $\mathrm{Fe}-\mathrm{FeO}-\mathrm{FeS}$ and $\mathrm{Fe}-\mathrm{Ni}-\mathrm{O}-\mathrm{S}$ systems (Urakawa et al., 1987). CMB represents the depth of the core-mantle boundary. 
On the basis of the observation that solubility of hydrogen into iron increases drastically with pressure, Fukai (1984) and Fukai and Suzuki (1986) proposed that formation of iron hydride at high pressure may play an important role during the core formation processes. Suzuki et al. $(1984,1989)$ demonstrated that the formation of iron hydride occurred at pressures of about $5 \mathrm{GPa}$ in the iron-silicate-water system, which was accompanied by a large decrease of melting temperature of the metallic phase by several hundred degrees. These experimental results imply that hydrogen is one of the most likely candidates for the light elements in the core, if water was effectively incorporated into the earth's interior in the accretional stage.

Very recently, partition experiments on transition metal elements among iron, silicates, and oxides were carried out at high pressure and high temperature. Urakawa (1991) examined partitioning of iron and nickel between magnesiowustite and the metallic phase, while Suzuki et al. (1992) determined the partition coefficients of iron, cobalt, and nickel between metal, olivine, and pyroxene. Ohtani et al. (1991) examined partitioning of several transition metal elements among Mg-perovskite, magnesiowustite, and metallic iron. Although the experiments were carried out in a limited pressure and temperature range, these partition data are useful to constrain the core segregation processes and to examine whether the core-mantle system is in equilibrium or not.

The nature of the core-mantle boundary and the $\mathrm{D}^{\prime \prime}$ layer in the lowermost mantle have been recently discussed based on mineral physics approaches. A preliminary study using a diamond anvil cell by Knittle and Jeanloz (1989b) revealed the occurrence of complex reactions between perovskite and molten iron under the core's $\mathrm{P}, \mathrm{T}$ conditions, and suggested that this reaction occurs in the $\mathrm{D}^{\prime \prime}$ region. Ito and Katsura (1991) found similar reactions with considerable dissolution of $\mathrm{Si}$ and $\mathrm{O}$ into molten iron from silicate melt at $24 \mathrm{GPa}$ and $2,550^{\circ} \mathrm{C}$. The solubility of these elements in molten iron was suggested to be further enhanced at higher pressures. Accordingly, both $\mathrm{Si}$ and $\mathrm{O}$ may be important light elements in the core, which would reduce the $\mathrm{SiO}_{2}$ content in the mantle from chondritic toward peridotitic compositions during the core-mantle separation.

\section{Concluding Remarks}

Using the multianvil techniques developed in 1980 s, the phase relations of mantle minerals were accurately determined under $\mathrm{P}, \mathrm{T}$ conditions corresponding to the uppermost lower mantle. Thermodynamic studies of the high pressure silicates provided detailed phase equilibrium diagrams which are in harmony with the experimental results. Physical properties, such as elastic moduli and thermal expansivities, of the high pressure silicates were also measured at the ambient pressure. Mineral physics tests based on these experimental results reveal that the upper mantle composition is consistent with pyrolite. Although the experimental data on the postspinel transition is consistent with the nature of the seismic $670 \mathrm{~km}$ discontinuity, the question of whether or not the lower mantle composition is the same as the upper mantle still remains to be solved in 1990s. Accurate determinations of the mineral physics parameters of lower mantle minerals are required to place tighter constraints on these issues. Possible transitions in silicate perovskite, predicted by the theoretical studies, should be investigated experimentally.

Melting experiments on model mantle rocks at $10-25 \mathrm{GPa}$ have clarified that the

Vol. 43, No. 4, 1995 
melting behavior of these materials at pressures corresponding to the transition zone and the lower mantle are very different from those under upper mantle conditions. These results strongly suggest that fractionation of majorite garnet and perovskite would have occurred and a stratified mantle would have been formed in the early stage of the formation of the earth, if the earth experienced extensive global melting. The formation and evolution processes of the magma ocean will be clarified in more detail by a combination of computer simulations and high pressure experimental studies in 1990s.

Some experiments on element partitioning and the reactions between core materials and silicates have been carried out in the 1980s. However, there is still active debate on the light elements in the core. These results are rather qualitative or preliminary; further studies are needed to clarify the present state and the formation processes of the core. Development of experimental and theoretical studies in mineral physics will help to clarify the composition of the core and the nature of the $\mathrm{D}^{\prime \prime}$ layer in 1990s.

Constructive comments by two anonymous reviewers were useful to improve the manuscript. This work was supported in part by Grants-in-Aid from the Ministry of Education, Science, and Culture of Japan.

\section{REFERENCES}

Abe, $Y$. and T. Matsui, The formation of an impact-generated $\mathrm{H}_{2} \mathrm{O}$ atmosphere and its implications for the early thermal history of the earth, J. Geophys. Res., 90, Suppl., C545-C559, 1985.

Akaogi, M. and S. Akimoto, High-pressure phase equilibria in a garnet lherzolite, with special reference to $\mathrm{Mg}^{2+}-\mathrm{Fe}^{2+}$ partitioning among constituent minerals, Phys. Earth Planet. Inter., 19, 31-51, 1979.

Akaogi, M. and S. Akimoto, High-pressure stability of a dense hydrous magnesian silicate $\mathrm{Mg}_{23} \mathrm{Si}_{8} \mathrm{O}_{42} \mathrm{H}_{6}$ and some geophysical implications, J. Geophys. Res., 85, 6944-6948, 1980.

Akaogi, M. and S. Akimoto, Infrared spectra of high-pressure hydrous silicates in the system $\mathrm{MgO}-\mathrm{SiO}_{2}-\mathrm{H}_{2} \mathrm{O}$, Phys. Chem. Minerals, 13, 161-164, 1986.

Akaogi, M. and E. Ito, Heat capacity of $\mathrm{MgSiO}_{3}$ perovskite, Geophys. Res. Lett., 20, 105-108, 1993.

Akaogi, M., E. Ito, and A. Navrotsky, Olivine-modified spinel-spinel transitions in the system $\mathrm{Mg}_{2} \mathrm{SiO}_{4}-\mathrm{Fe}_{2} \mathrm{SiO}_{4}$ : calorimetric measurements, thermochemical calculation, and geophysical application, J. Geophys. Res., 94, 15671-15685, 1989.

Akaogi, M., A. Navrotsky, T. Yagi, and S. Akimoto, Pyroxene-garnet transformation: thermochemistry and elasticity of garnet solid solutions, and application to a pyrolite mantle, in High-Pressure Research in Mineral Physics, ed. M. H. Manghnani and Y. Syono, pp. 251-260, Terra Sci. Publ., Tokyo/Am. Geophys. Union, Washington, D. C., 1987.

Akaogi, M., N. L. Ross, P. McMillan, and A. Navrotsky, The $\mathrm{Mg}_{2} \mathrm{SiO}_{4}$ polymorphs (olivine, modified spinel and spinel) - thermodynamic properties from oxide melt solution calorimetry, phase relations, and models of lattice vibrations, Am. Mineral., 69, 499-512, 1984.

Akimoto, S., High-pressure research in geophysics: past, present and future, in High-Pressure Research in Mineral Physics, ed. M. H. Manghnani and Y. Syono, pp. 1-13, Terra Sci. Publ., Tokyo/Am. Geophys. Union, Washington, D. C., 1987.

Akimoto, S., T. Suzuki, T. Yagi, and O. Shimomura, Phase diagram of iron determined by 
high-pressure/temperature $\mathrm{x}$-ray diffraction using synchrotron radiation, in High-Pressure Research in Mineral Physics, ed. M. H. Manghnani and Y. Syono, pp. 149-154, Terra Sci. Publ., Tokyo/Am. Geophys. Union, Washington, D. C., 1987.

Anderson, D. L. and J. D. Bass, Transition region of the earth's upper mantle, Nature, 320, 321-328, 1986.

Ashida, T., S. Kume, and E. Ito, Thermodynamic aspects of phase boundary among $\alpha-, \beta$-, and $\gamma-\mathrm{Mg}_{2} \mathrm{SiO}_{4}$, in High-Pressure Research in Mineral Physics, ed. M. H. Manghnani and $\mathrm{Y}$. Syono, pp. 269-274, Terra Sci. Publ., Tokyo/Am. Geophys. Union, Washington, D. C., 1987.

Ashida, T., S. Kume, E. Ito, and A. Navrotsky, $\mathrm{MgSiO}_{3}$ ilmenite: heat capacity, thermal expansivity, and enthalpy of transformation, Phys. Chem. Minerals, 16, 239-245, 1988.

Chopelas, A. and R. Boehler, Thermal expansion measurements at very high pressure, systematics, and a case for a chemically homogeneous mantle, Geophys. Res. Lett., 16, 1347-1350, 1989.

Duffy, T. S. and D. L. Anderson, Seismic velocities in mantle minerals and the mineralogy of the upper mantle, J. Geophys. Res., 94, 1895-1912, 1989.

Dziewonski, A. M. and D. L. Anderson, Preliminary reference earth model, Phys. Earth Planet. Inter., 25, 297-356, 1981.

Finger, L. W., J. Ko, R. M. Hazen, T. Gasparik, R. J. Hemley, C. T. Prewitt, and D. J. Weidner, Crystal chemistry of phase B and an anhydrous analogue: implications for water storage in the upper mantle, Nature, 341, 140-142, 1989.

Fujisawa, H. and E. Ito, 'Measurements of ultrasonic wave velocities in solid under high pressure, Proc. 4th Symp. Untrasonic Electronics, Jpn. J. Appl. Phys., 23, Suppl. 23-1, 51-53, 1984.

Fukai, Y., The iron-water reaction and the evolution of the earth, Nature, 308, 174-175, 1984.

Fukai, Y. and T. Suzuki, Iron-water reaction under high pressure and its implication in the evolution of the earth, J. Geophys. Res., 91, 9222-9230, 1986.

Grand, S. and D. V. Helmberger, Upper mantle shear structure of North America, Geophys. $J$. R. Astron. Soc., 76, 399-438, 1984.

Gwanmesia, G. D., S. Rigden, I. Jackson, and R. C. Liebermann, Pressure dependence of elastic wave velocity of $\beta-\mathrm{Mg}_{2} \mathrm{SiO}_{4}$ and composition of the earth's mantle, Science, 250, 794-797, 1990.

Irifune, T., An experimental investigation of the pyroxene-garnet transformation in a pyrolite composition and its bearing on the constitution of the mantle, Phys. Earth Planet. Inter., 45, 324-336, 1987.

Irifune, T. and A. E. Ringwood, Phase transformations in a harzburgite composition to $26 \mathrm{GPa}$ : implications for dynamical behaviour of the subducting slab, Earth Planet. Sci. Lett., 86, 365-376, 1987a.

Irifune, T. and A. E. Ringwood, Phase transformations in primitive MORB and pyrolite compositions to $25 \mathrm{GPa}$ and some geophysical implications, in High-Pressure Research in Mineral Physics, ed. M. H. Manghnani and Y. Syono, pp. 231-242, Terra Sci. Publ., Tokyo/Am. Geophys. Union, Washington, D. C., 1987b.

Irifune, T., K. Fujino, and E. Ohtani, A new high-pressure form of $\mathrm{MgAl}_{2} \mathrm{O}_{4}$, Nature, 349 , 409-411, 1991.

Irifune, T., J. Susaki, T. Yagi, and H. Sawamoto, Phase transformations in diopside $\mathrm{CaMgSi}_{2} \mathrm{O}_{6}$ up to $25 \mathrm{GPa}$, Geophys. Res. Lett., 16, 187-190, 1989.

Ito, E. and T. Katsura, A temperature profile of the mantle transition zone, Geophys. Res. Lett., 16, 425-428, 1989.

Ito, E. and T. Katsura, Dissolution of silicon and oxygen in molten iron at high pressure and temperature, Proc. Jpn. Acad., 67, 153-158, 1991.

Vol. 43, No. 4, 1995 
Ito, E. and A. Navrotsky, $\mathrm{MgSiO}_{3}$ ilmenite: calorimetry, phase equilibria, and decomposition at atmospheric pressure, Am. Mineral., 70, 1020-1026, 1985.

Ito, E. and E. Takahashi, Ultrahigh-pressure phase transformations and the constitution of the deep mantle, in High-Pressure Research in Mineral Physics, ed. M. H. Manghnani and Y. Syono, pp. 221-229, Terra Sci. Publ., Tokyo/Am. Geophys. Union, Washington, D. C., 1987a.

Ito, E. and E. Takahashi, Melting of peridotite at uppermost lower-mantle conditions, Nature, 328, 514-517, 1987b.

Ito, E. and E. Takahashi, Postspinel transformations in the system $\mathrm{Mg}_{2} \mathrm{SiO}_{4}-\mathrm{Fe}_{2} \mathrm{SiO}_{4}$ and some geophysical implications, J. Geophys. Res., 94, 10637-10646, 1989.

Ito, E. and D. J. Weidner, Crystal growth of $\mathrm{MgSiO}_{3}$ perovskite, Geophys. Res. Lett., 13, 464-466, 1986.

Ito, E. and H. Yamada, Stability relations of silicate spinels, ilmenites, and perovskites, in High-Pressure Research in Geophysics, ed. S. Akimoto and M. H. Manghnani, pp. 405-419, Center for Academic Publications Japan, Tokyo, 1982.

Ito, E., M. Akaogi, L. Topor, and A. Navrotsky, Negative pressure-temperature slopes for reactions forming $\mathrm{MgSiO}_{3}$ perovskite from calorimetry, Science, 249, 1275-1278, 1990.

Jackson, I., Some geophysical constraints on the chemical composition of the earth's lower mantle, Earth Planet. Sci. Lett., 62, 91-103, 1983.

Jeanloz, R., Majorite: vibrational and compressional properties of a high-pressure phase, $J$. Geophys. Res., 86, 6171-6179, 1981.

Jeanloz, R. and A. B. Thompson, Phase transitions and mantle discontinuities, Rev. Geophys. Space Phys., 21, 51-74, 1983.

Kanzaki, M., Ultrahigh-pressure phase relations in the system $\mathrm{Mg}_{4} \mathrm{Si}_{4} \mathrm{O}_{12}-\mathrm{Mg}_{3} \mathrm{Al}_{2} \mathrm{Si}_{3} \mathrm{O}_{12}$, Phys. Earth Planet. Inter., 49, 168-175, 1987.

Kanzaki, M., Stability of hydrous magnesium silicates in the mantle transition zone, Phys. Earth Planet. Inter., 66, 307-312, 1991.

Kanzaki, M., K. Kurita, T. Fujii, T. Kato, O. Shimomura, and S. Akimoto, A new technique to measure the viscosity and density of silicate melts at high pressure, in High-Pressure Research in Mineral Physics, ed. M. H. Manghnani and Y. Syono, pp. 195-200, Terra Sci. Publ., Tokyo/Am. Geophys. Union, Washington, D. C., 1987.

Kato, T. and M. Kumazawa, Garnet phase of $\mathrm{MgSiO}_{3}$ filling the pyroxene-ilmenite gap at very high temperature, Nature, 316, 803-805, 1985a.

Kato, T. and M. Kumazawa, Stability of phase B, a hydrous magnesium silicate, to $2,300^{\circ} \mathrm{C}$ at $20 \mathrm{GPa}$, Geophys. Res. Lett., 12, 534-535, 1985b.

Kato, T. and A. E. Ringwood, Melting relationships in the system $\mathrm{Fe}-\mathrm{FeO}$ at high pressures: implications for composition and formation of the earth's core, Phys. Chem. Minerals, 16, 524-538, 1989.

Kato, T., A. E. Ringwood, and T. Irifune, Experimental determination of element partitioning between silicate perovskites, garnets, and liquids: constraints on early differentiation of the mantle, Earth Planet. Sci. Lett., 89, 123-145, 1988a.

Kato, T., A. E. Ringwood, and T. Irifune, Constraints on element partition coefficients between $\mathrm{MgSiO}_{3}$ perovskite and liquid determined by direct measurements, Earth Planet. Sci. Lett., 90, 65-68, 1988b.

Katsura, T. and E. Ito, The system $\mathrm{Mg}_{2} \mathrm{SiO}_{4}-\mathrm{Fe}_{2} \mathrm{SiO}_{4}$ at high pressures and temperatures: precise determination of stabilities of olivine, modified spinel, and spinel, J. Geophys. Res., 94, 15663-15670, 1989. 
Knittle, E. and R. Jeanloz, Melting curve of $(\mathrm{Mg}, \mathrm{Fe}) \mathrm{SiO}_{3}$ perovskite to $96 \mathrm{GPa}$ : evidence for a structural transition in lower mantle melt, Geophys. Res. Lett., 16, 421-424, 1989a.

Knittle, E. and R. Jeanloz, Simulating the core-mantle boundary: an experimental study of high-pressure reactions between silicates and liquid iron, Geophys. Res. Lett., 16, 609-612, 1989b.

Knittle, E. and R. Jeanloz, The high pressure phase diagram of $\mathrm{Fe}_{0.94} \mathrm{O}$ : a possible constituent of the earth's core, J. Geophys. Res., 96, 16169-16180, 1991.

Lees, A. C., M. S. T. Bukowinski, and R. Jeanloz, Reflection properties of phase transition and compositional change models of the 670-km discontinuity, J. Geophys. Res., 88, 8145-8159, 1983.

Liu, L. G., A new high-pressure phase of spinel, Earth Planet. Sci. Lett., 41, 398-404, 1978.

Madon, M., J. Castex, and J. Peyronneau, A new aluminocalcic high-pressure phase as a possible host of calcium and aluminium in the lower mantle, Nature, 342, 422-425, 1989.

Matsui, M., Molecular dynamics study of $\mathrm{MgSiO}_{3}$ perovskite, Phys. Chem. Minerals, 16, 234-238, 1988.

Matsui, M. and G. D. Price, Simulation of pre-melting behaviour of $\mathrm{MgSiO}_{3}$ perovskite at high pressures and temperatures, Nature, 351, 735-737, 1991.

Matsui, Y. and K. Kawamura, Computer-experimental synthesis of silica with $\alpha-\mathrm{PbO}_{2}$ structure, in High-Pressure Research in Mineral Physics, ed, M. H. Manghnani and Y. Syono, pp. 305-311, Terra Sci. Publ., Tokyo/Am. Geophys. Union, Washington, D. C., 1987.

Matsui, Y. and M. Matsui, Molecular dynamics studies of polymorphism of $\mathrm{SiO}_{2}$ at high pressures: a possible new cubic polymorph with high density, in Structural and Magnetic Phase Transitions in Minerals, ed. S. Ghose, E. Salje, and J. M. D. Coey, pp. 129-140, Springer, New York, 1988.

Matsui, M., M. Akaogi, and T. Matsumoto, Computational model of the structural and elastic properties of the ilmenite and perovskite phases of $\mathrm{MgSiO}_{3}$, Phys. Chem. Minerals, 14, 101-106, 1987.

Nakanishi, I., Reflections of $\mathrm{P}^{\prime} \mathrm{P}^{\prime}$ from upper mantle discontinuities beneath the mid-Atlantic ridge, Geophys. J., 93, 335-346, 1988.

Ohtani, E., Melting relation of $\mathrm{Fe}_{2} \mathrm{SiO}_{4}$ up to about 200 kbar, J. Phys. Earth, 27, 189-208, 1979.

Ohtani, E. and M. Kumazawa, Melting of forsterite $\mathrm{Mg}_{2} \mathrm{SiO}_{4}$ up to $15 \mathrm{GPa}$, Phys. Earth Planet. Inter., 27, 32-38, 1981.

Ohtani, E. and H. Sawamoto, Melting experiments on a model chondritic mantle composition at $25 \mathrm{GPa}$, Geophys. Res. Lett., 14, 733-736, 1987.

Ohtani, E., T. Kato, and E. Ito, Transition metal partitioning between lower mantle and core materials at $27 \mathrm{GPa}$, Geophys. Res. Lett., 18, 85-88, 1991.

Ohtani, E., A. E. Ringwood, and W. Hibberson, Composition of the core, II. Effect of high pressure on solubility of $\mathrm{FeO}$ in molten iron, Earth Planet. Sci. Lett., 71, 94-103, 1984.

Ohtani, E., I. Kawabe, J. Moriyama, and Y. Nagata, Partitioning of elements between majorite garnet and melt and implications for petrogenesis of komatiite, Contrib. Mineral. Petrol., 103, 263-269, 1989.

Park, K. T., K. Terakura, and Y. Matsui, Theoretical evidence for a new ultrahigh-pressure phase of $\mathrm{SiO}_{2}$, Nature, 336, 670-672, 1988.

Presnall, D. C. and T. Gasparik, Melting of enstatite $\left(\mathrm{MgSiO}_{3}\right)$ from 10 to $16.5 \mathrm{GPa}$ and the forsterite $\left(\mathrm{Mg}_{2} \mathrm{SiO}_{4}\right)$-majorite $\left(\mathrm{MgSiO}_{3}\right)$ eutectic at $16.5 \mathrm{GPa}$ : implication for origin of the mantle, J. Geophys. Res., 95, 15771-15777, 1990. 
Rigden, S. M., G. D. Gwanmesia, J. D. Fitz Gerald, I. Jackson, and R. C. Libermann, Spinel elasticity and seismic structure of the transition zone of the mantle, Nature, 354, 143-145, 1991.

Ringwood, A. E., Origin of the Earth and Moon, Springer, New York, 285 pp., 1979.

Ross, N. L. and R. M. Hazen, Single crystal x-ray diffraction study of $\mathrm{MgSiO}_{3}$ perovskite from 77 to $400 \mathrm{~K}$, Phys. Chem. Minerals, 16, 415-420, 1989.

Sasaki, S. and K. Nakazawa, Metal-silicate fractionation in the growing earth: energy source for the terrestrial magma ocean, J. Geophys. Res., 91, 9231-9238, 1986.

Sawamoto, $\mathrm{H}$., Single crystal growth of modified spinel $(\beta)$ and spinel $(\gamma)$ phases of $(\mathrm{Mg}, \mathrm{Fe})_{2} \mathrm{SiO}_{4}$ and some geophysical implications, Phys. Chem. Minerals, 13, 1-10, 1986.

Sawamoto, H., Phase diagram of $\mathrm{MgSiO}_{3}$ at high pressures up to $24 \mathrm{GPa}$ and temperatures up to $2,200^{\circ} \mathrm{C}$ : phase stability and properties of tetragonal garnet, in High-Pressure Research in Mineral Physics, ed. M. H. Manghnani and Y. Syono, pp. 209-219, Terra Sci. Publ., Tokyo/Am. Geophys. Union, Washington, D. C., 1987.

Sawamoto, H., D. J. Weidner, S. Sasaki, and M. Kumazawa, Single crystal elastic properties of the modified spinel (beta) phase of $\mathrm{Mg}_{2} \mathrm{SiO}_{4}$, Science, 224, 749-751, 1984.

Silver, P. G., R. W. Carlson, and P. Olson, Deep slabs, geochemical heterogeneity, and the large-scale structure of mantle convection: investigation of an enduring paradox, Ann. Rev. Earth Planet. Sci., 16, 477-541, 1988.

Stolper, E., D. Walker, B. H. Hager, and J. F. Hays, Melt segregation from partially molten source region: the importance of melt density and source region size, J. Geophys. Res., 86, 6261-6271, 1981.

Sumino, Y., The elastic constants of $\mathrm{Mn}_{2} \mathrm{SiO}_{4}, \mathrm{Fe}_{2} \mathrm{SiO}_{4}$ and $\mathrm{Co}_{2} \mathrm{SiO}_{4}$, and the elastic properties of olivine group minerals at high temperature, J. Phys. Earth, 27, 209-238, 1979.

Sumino, Y., O. L. Anderson, and I. Suzuki, Temperature coefficients of elastic constants of single crystal MgO between 80 and 1,300 K, Phys. Chem. Minerals, 9, 38-47, 1983.

Suzuki, I. and O. L. Anderson, Elasticity and thermal expansion of a natural garnet up to $1,000 \mathrm{~K}$, J. Phys. Earth, 31, 125-138, 1983.

Suzuki, I., E. Ohtani, and M. Kumazawa, Thermal expansion of $\gamma-\mathrm{Mg}_{2} \mathrm{SiO}_{4}, J$. Phys. Earth, 27, 53-61, 1979.

Suzuki, I., E. Ohtani, and M. Kumazawa, Thermal expansion of modified spinel, $\beta-\mathrm{Mg}_{2} \mathrm{SiO}_{4}, J$. Phys. Earth, 28, 273-280, 1980.

Suzuki, I., K. Seya, H. Takei, and Y. Sumino, Thermal expansion of fayalite, $\mathrm{Fe}_{2} \mathrm{SiO}_{4}$, Phys. Chem. Minerals, 7, 60-63, 1981.

Suzuki, T., S. Akimoto, and Y. Fukai, The system iron-enstatite-water at high pressures and temperatures-formation of iron hydride and some geophysical implications, Phys. Earth Planet. Inter., 36, 135-144, 1984.

Suzuki, T., S. Akimoto, and T. Yagi, Metal-silicate-water reaction under high pressure. I. Formation of metal hydride and implications for composition of the core and mantle, Phys. Earth Planet. Inter., 56, 377-388, 1989.

Suzuki, T., S. Akimoto, and T. Yagi, Metal-silicate-water reaction under high pressure. II. Partition of $\mathrm{Fe}, \mathrm{Ni}$, and $\mathrm{Co}$ between metal and silicate, Phys. Earth Planet. Inter., 69, 163-175, 1992.

Takahashi, E., Melting of a dry peridotite KLB-1 up to $14 \mathrm{GPa}$ : implications on the origin of peridotitic upper mantle, J. Geophys. Res., 91, 9367-9382, 1986.

Takahashi, E. and E.Ito, Mineralogy of mantle peridotite along a model geotherm up to $700 \mathrm{~km}$ depth, in High-Pressure Research in Mineral Physics, pp. 427-437, Terra Sci. Publ., Tokyo/Am. Geophys. Union, Washington, D. C., 1987. 
Takahashi, E. and C. M. Scarfe, Melting of peridotite to $14 \mathrm{GPa}$ and the genesis of komatiite, Nature, 315, 566-568, 1985.

Tamai, H. and T. Yagi, High-pressure and high-temperature phase relations in $\mathrm{CaSiO}_{3}$ and $\mathrm{CaMgSi}_{2} \mathrm{O}_{6}$ and elasticity of perovskite-type $\mathrm{CaSiO}_{3}$, Phys. Earth Planet. Inter., 54, 370-377, 1989.

Taniguchi, $\mathrm{H}$., Densities of melts in the system $\mathrm{CaMgSi}_{2} \mathrm{O}_{6}-\mathrm{CaAl}_{2} \mathrm{Si}_{2} \mathrm{O}_{8}$ at low and high pressures, and their structural significance, Contrib. Mineral. Petrol., 103, 325-334, 1989.

Tsuchida, Y. and T. Yagi, A new post-stishovite high-pressure polymorph of silica, Nature, 340, 217-220, 1989.

Urakawa, S., Partitioning of Ni between magnesiowustite and metal at high pressure: implications for core-mantle equilibrium, Earth Planet. Sci. Lett., 105, 293-313, 1991.

Urakawa, S., M. Kato, and M. Kumazawa, Experimental study of the phase relations in the system Fe-Ni-O-S up to $15 \mathrm{GPa}$, in High-Pressure Research in Mineral Physics, ed. M. H. Manghnani and Y. Syono, pp. 95-111, Terra Sci. Publ., Tokyo/Am. Geophys. Union, Washington, D. C., 1987.

Walck, M. C., The P-wave upper mantle structure beneath an active spreading center: the Gulf of California, Geophys. J. R. Astron. Soc., 76, 697-723, 1984.

Wang, Y., D. J. Weidner, R. C. Liebermann, X. Liu, J. Ko, M. T. Vaughan, Y. Zhao, A. Yeganeh-Haeri, and R. E. G. Pacalo, Phase transition and thermal expansion of $\mathrm{MgSiO}_{3}$ perovskite, Science, 251, 410-413, 1991.

Watanabe, H., Thermochemical properties of synthetic high-pressure compounds relevant to the earth's mantle, in High-Pressure Research in Geophysics, ed. S. Akimoto and M. H. Manghnani, pp. 441-464, Center for Academic Publications Japan, Tokyo, 1982.

Weidner, D. J. and E. Ito, Elasticity of $\mathrm{MgSiO}_{3}$ in the ilmenite phase, Phys. Earth Planet. Inter., 40, 65-70, 1985.

Weidner, D. J. and E. Ito, Mineral physics constraints on a uniform mantle composition, in High-Pressure Research in Mineral Physics, ed. M. H. Manghnani and Y. Syono, pp. 439-446, Terra Sci. Publ., Tokyo/Am. Geophys. Union, Washington, D. C., 1987.

Weidner, D. J., H. Sawamoto, S. Sasaki, and M. Kumazawa, Single-crystal elastic properties of the spinel phase of $\mathrm{Mg}_{2} \mathrm{SiO}_{4}, J$. Geophys. Res., 89, 7852-7860, 1984.

Williams, Q. and R. Jeanloz, Melting relations in the iron-sulfur system at ultrahigh pressures: implications for the thermal state of the earth, J. Geophys. Res., 95, 19299-19310, 1990.

Williams, Q., R. Jeanloz, J. Bass, B. Svendsen, and T. J. Ahrens, The melting curve of iron to 250 Gigapascals: a constraint on the temperature at earth's center, Science, 236, 181-182, 1987.

Wolf, G. H. and M. S. T. Bukowinski, Theoretical study of the structural properties and equations of state of $\mathrm{MgSiO}_{3}$ and $\mathrm{CaSiO}_{3}$ perovskites: implications for lower mantle composition, in High-Pressure Research in Mineral Physics, ed. M. H. Manghnani and Y. Syono, pp. 313-331, Terra Sci. Publ., Tokyo/Am. Geophys. Union, Wahington, D. C. , 1987.

Yagi, T., S. Kusanagi, Y. Tsuchida, and Y. Fukai, Isothermal compression and stability of perovskite-type $\mathrm{CaSiO}_{3}$, Proc. Jpn. Acad., 65, 129-132, 1989.

Yagi, T., Y. Uchiyama, M. Akaogi, and E. Ito, Isothermal compression curve of $\mathrm{MgSiO}_{3}$ tetragonal garnet, Phys. Earth Planet. Inter., 74, 1-7, 1992.

Yagi, T., M. Akaogi, O. Shimomura, T. Suzuki, and S. Akimoto, In situ observation of the olivine-spinel phase transition in $\mathrm{Fe}_{2} \mathrm{SiO}_{4}$ using synchrotron radiation, J. Geophys. Res., 92 , 6207-6213, 1987.

Yagi, T., M. Akaogi, O. Shimomura, H. Tamai, and S. Akimoto, High pressure and high

Vol. 43, No. 4, 1995 
temperature equations of state of majorite, in High-Pressure Research in Mineral Physics, ed. M. H. Manghnani and Y. Syono, pp. 141-147, Terra. Sci. Publ., Tokyo/Am. Geophys. Union, Washington, D. C., 1987.

Yamanaka, T., Crystal structures of $\mathrm{Ni}_{2} \mathrm{SiO}_{4}$ and $\mathrm{Fe}_{2} \mathrm{SiO}_{4}$ as a function of temperature and heating duration, Phys. Chem. Minerals, 13, 227-232, 1986.

Yeganeh-Haeri, A., D. J. Weidner, and E. Ito, Elasticity of $\mathrm{MgSiO}_{3}$ in the perovskite structure, Science, 243, 787-789, 1989.

Yoneda, A., Pressure derivatives of elastic constants of single crystal $\mathrm{MgO}$ and $\mathrm{MgAl}_{2} \mathrm{O}_{4}, J$. Phys. Earth, 38, 19-55, 1990.

Yurimoto, H. and E. Ohtani, Element partitioning between majorite and liquid: a secondary ion mass spectropic study, Geophys. Res. Lett., 19, 17-20, 1992.

Yusa, H., M. Akaogi, and E. Ito, Calorimetric study of $\mathrm{MgSiO}_{3}$ garnet and pyroxene: heat capacities, transition enthalpies and equilibrium phase relations in $\mathrm{MgSiO}_{3}$ at high pressures and temperatures, J. Geophys. Res., 98, 6453-6460, 1993. 